\title{
Penerapan Diskon Dalam Menarik Minat Beli Konsumen Di Matahari Departement Store Kediri Town Square
}

\author{
Denok Wahyudi Setyo Rahayu ${ }^{1}$ \\ ${ }^{1}$ Fakultas Ekonomi Universitas Islam Balitar \\ email: ${ }^{1}$ denok.wahyudisr@gmail.com
}

\begin{tabular}{l}
\hline Kata kunci: \\
Diskon \\
Minat Beli \\
Harga \\
Daya Tarik \\
\hline
\end{tabular}

\section{Keywords:}

Discount

Purchase Interest

Price

Attractiveness

\section{Rahayu, D.W. S. (2019).}

Penerapan Diskon Dalam Menarik Minat Beli Konsumen Di Matahari Departement Store Kediri Town Square. Akuntabilitas: Jurnal Ilmiah Ilmu-Ilmu Ekonomi, 12(2), 42-51

\begin{abstract}
ABSTRAK
Pemasaran yang baik akan menimbulkan minat beli konsumen. Salah satu cara melalui pemberian diskon. Tujuan penelitian adalah untuk mengetahui sejauh mana keterkaitan antara penerapan diskon dalam menarik minat beli konsumen di Matahari Departement Store Kediri Town Square. Metode penelitian menggunakan pengamatan langsung dan wawancara kepada pembeli produk pakaian. Populasi penelitian adalah pembeli produk pakaian berbagai merek dengan teknik sampling menggunakan accidental sampling yaitu siapa saja yang secara kebetulan bertemu dengan peneliti. Variabel yang digunakan adalah diskon dengan indikator harga murah dan jumlah pembelian pakaian serta variabel minat beli dengan indikator membeli pakaian. Penerapan diskon diharapkan dapat menimbulkan minat beli di benak konsumen. Hasil penelitian menunjukkan bahwa penerapan diskon dapat memberi dampak minat beli bagi konsumen produk pakaian di Matahari Departement Store Kediri Town Square. Diskon menjadi daya tarik konsumen untuk membeli produk pakaian di tempat tersebut.
\end{abstract}

\section{ABSTRACT}

Good marketing will cause consumer buying interest. One way through giving discounts. The research objective is to determine the extent of the relationship between the application of discounts in attracting consumer buying interest at Matahari Department Store Kediri Town Square. The research method uses direct observation and interviews with buyers of clothing products. The study population was buyers of various brands of clothing products with a sampling technique using accidental sampling, ie anyone who happened to meet with researchers. The variable used is a discount with a low price indicator and the number of clothing purchases as well as a buying interest variable with an indicator of buying clothes. Application of discounts is expected to cause buying interest in the minds of consumers. The results showed that the application of discounts can have an impact on buying interest for consumers of clothing products at Matahari Department Store Kediri Town Square. Discounts are the main attraction for consumers to buy clothing products in these places.

\section{PENDAHULUAN}


Pemasaran merupakan kegiatan yang tidak terlepas dalam kehidupan manusia. Pemasaran sangat penting untuk keberlanjutan siklus hidup suatu produk (Rahayu, 2018 : 20-27). Siklus hidup produk merupakan kedudukan produk dalam suatu tempat. Kedudukan produk menentukan minat konsumen dalam menentukan pilihan produk untuk dikonsumsi. Pemasaran berlanjut pada kegiatan konsumsi atau belanja di lingkungan masyarakat.

Kegiatan belanja merupakan suatu kegiatan yang biasa dilakukan oleh manusia. Berbagai produk yang ditawarkan penjual diharapkan dapat diminati oleh para calon pembeli. Penjual akan berupaya melakukan berbagai cara untuk menarik perhatian konsumen selaku pembeli produk. Promosi merupakan salah satu dari sekian cara yang diterapkan penjual selaku produsen. Berbagai macam promosi menjadi sajian dalam memberi daya tarik produk yang dijual. Keberadaan promosi tersebut dapat menciptakan minat beli konsumen. Terbentuknya minat beli di benak konsumen dapat memberi efek kegiatan belanja atau konsumsi yang dilakukan oleh konsumen.

Promosi sebagai wadah yang digunakan penjual dalam upaya menarik simpati minat beli. Promosi merupakan suatu usaha yang dilakukan oleh pemasar atau penjual melalui komunikasi dengan calon pembeli. Komunikasi sebagai suatu proses memberikan ide, informasi, ataupun perasaan para audiens selaku calon pembeli (Alma, 2004: 179). Dalam kaitan dengan penjualan, promosi dikatakan penting. Promosi yang dibuat menarik dapat menumbuhkan keinginan konsumen untuk mengkonsumsi produk tersebut.

Keinginan minat beli merupakan sebuah perilaku atau sikap dari konsumen yang mempunyai keinginan dalam membeli atau menentukan pilihan dari suatu produk, hal tersebut berdasarkan pengalaman dalam memilih atau menentukan, serta menggunakan dan mengkonsumsi atau bahkan dalam menginginkan suatu produk yang ditawarkan penjual (Kotler dan Keller, 2012 : 131). Minat beli konsumen sebagai suatu pemikiran atau inisiatif dari pembeli dalam menentukan sikap dalam pengambilan keputusan untuk membeli sebuah produk (Oentoro, 2012). Minat beli terjadi karena adanya ketertarikan konsumen pada suatu produk. Ketertarikan tersebut akan diikuti oleh kegiatan membeli produk yang dimaksud. 
Minat beli terukur melalui indikator harga produk yang terjangkau, kemudahan cara pembayaran, pemberian potongan harga atau diskon (Wibowo dan Japarianto, 2013).

Upaya dalam menarik minat beli konsumen dapat berupa pemberlakuan potongan harga atau yang sering disebut diskon. Kata diskon menjadi hal menarik bagi pembeli. Diskon sebagai upaya dalam pengurangan harga secara langsung terhadap suatu produk yang dibeli pada waktu tertentu yang dilakukan oleh penjual kepada konsumen (Kotler dan Armstrong, 2008:9). Potongan harga atau diskon dapat juga diartikan sebagai bentuk promosi penjualan yang terbilang sederhana oleh penjual atau produsen dikarenakan hanya berupa pengurangan harga produk yang dibeli konsumen dan bersifat sementara (Boyd, et al. 2010:90). Diskon sebagai harga yang lebih rendah dari harga yang seharusnya dibayar konsumen berdasar pada hal-hal antara lain : waktu pembayaran produk yang lebih awal, tingkat serta jumlah pembelian produk serta pembelian pada musim tertentu yang dilakukan konsumen (Gitosudarmo, 2012:233). Keberadaan diskon sebagai upaya produsen diharapkan dapat menjadi pemicu tersendiri dalam peningkatan minat beli bagi konsumen sehingga konsumen berkeinginan melakukan transaksi terhadap produk yang ditawarkan produsen.

Jenis diskon terbagi menjadi tiga (Kotler dan Keller, 2007:104), yaitu : diskon tunai, diskon musim, dan potongan harga. Diskon bentuk tunai sebagai potongan harga yang diterima pembeli yang melakukan pembayaran langsung saat transaksi. Diskon musim sebagai potongan suatu nilai atau harga bagi konsumen yang melakukan pembelian produk diluar musim atau di hari besar. Potongan harga merupakan nilai potongan suatu harga yang diberikan kepada konsumen dari harga seharusnya atau resmi produk. Diskon merupakan bagian menarik bagi konsumen. Keberagaman penawaran diskon merupakan cara penjual menatikm perhatian konsumen.

Kediri Town Square merupakan tempat belanja di Kota Kediri yang menyajikan Matahari Departement Store sebagai salah satu media belanja konsumen. Matahari Departement Store merupakan suatu tepat yang menyajikan produk-produk berkualitas. Pakaian, tas, sepatu, mainan anak-anak dan lain-lain disajikan di tempat tersebut. Penataan yang rapi dan desain ruang yang menarik 
menjadi sarana sajian yang ditawarkan. Produk yang disajikanpun beragam. Konsumen dapat memilih produk yang diinginkan. Ketersediaan produk dengan diskon menarik sebagai upaya yang diharapkan penjual dapat menjadi penarik minat di benak konsumen untuk menumbuhkan minat berdaya beli. Terbentuknya minat beli akan memberi keuntungan bagi Matahari Departement Store karena produk yang tersaji akan terjual. Berbagai bentuk diskon ditawarkan di tempat tersebut. Misal terdapat perbedaan antara membeli satu, dua, atau tiga produk pakaian. Jika membeli tiga pakaian akan mendapat diskon yaitu satu pakaian dengan harga terendah diberikan gratis kepada pembeli.

Keanekaragaman metode pemberian diskon dilakukan dalam rangka menarik minat beli konsumen. Konsumen dapat memilih metode diskon yang diinginkan. Konsumen dapat menyesuaikan dengan keperluan. Meskipun hanya membeli satu produk pakaian, pemberlakuan diskon akan tetap diperoleh konsumen. Pada dasarnya terdapat konsumen yang hanya memerlukan membeli satu produk saja, namun ada pula konsumen yang akan lebih tertarik untuk membeli dengan jumlah lebih banyak untuk memanfaatkan metode diskon tersebut. Metode diskon diberlakukan untu menarik minat beli konsumen.

Putra E.W., Kumadji, S., dan Yulianto, E (2016), dalam penelitian menyatakan diskon secara signifikan terhadap minat dalam pembelian konsumen; namun diskon tidak berpengaruh signifikan terhadap tindakan keputusan pembelian; sedang minat beli memiliki pengaruh secara signifikan terhadap keputusan pembelian. Sudrajat dkk (2017) menyatakan bahwa potongan harga berpengaruh signifikan terhadap minat beli. Sikap atau perilaku konsumen terhadap diskon dan hadiah memiliki efektifitas dalam mempengaruhi niat beli konsumen dalam penentuan produk yang akan dibeli atau dikonsumsi (Faesol, 2013).

Pada penelitian pemasalahan yang dikaji adalah mengenai penerapan diskon dalam menarik minat beli. Berdasarkan hal tersebut, sehingga penelitian memiliki tujuan untuk mengetahui sejauh mana keterkaitan antara penerapan diskon dalam menarik minat beli konsumen di Matahari Departement Store Kediri Town Square.

\section{METODE PENELITIAN}

Penerapan Diskon Dalam Menarik Minat Beli Konsumen Di Matahari Departement Store Kediri Town Square 
Kegiatan penelitian yang dilakukan pada bulan Juni 2019 dengan lokasi penelitian di Matahari Departement Store Kediri Town Square. Metode penelitian menggunakan pengamatan secara langsung dan wawancara di lokasi penelitian. Populasi penelitian adalah pembeli produk pakaian berbagai merek dengan teknik sampling menggunakan accidental sampling yaitu pembeli produk yang bertemu dengan peneliti di lokasi penelitian. Variabel penelitian adalah diskon dengan indikator harga murah dan jumlah pembelian pakaian (Gitosudarmo, 2012 : 233), sedangkan variabel minat beli dengan indikator membeli pakaian (Kotler dan Keller, 2012 : 131). Melalui pengamatan akan dilihat bagaimana respon pembeli sebagai konsumen pada diskon yang ditawarkan apakah konsumen akan tertarik dan memiliki minat membeli atau tidak. Pengamatan dilakukan dengan mengamati minat belanja konsumen pada produk yang dijual. Wawancara dilakukan dengan mengajukan pertanyaan kepada para pembeli produk pakaian secara langsung mengenai alasan melakukan kegiatan belanja tersebut yang berkenaan dengan pemberian diskon.
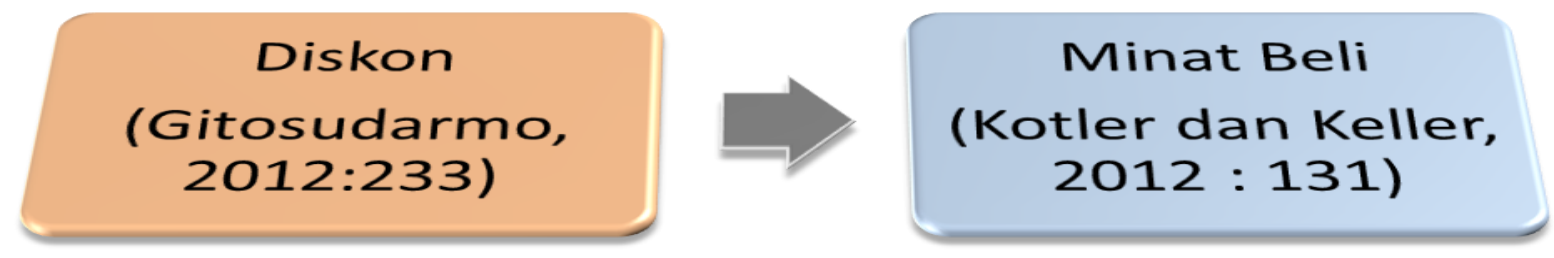

Gambar 1. Kerangka Konsep Penelitian, diolah, 2019

Pada gambar 1 terdapat variabel diskon yang mengarah pada variabel minat beli. Diskon dengan indikator harga murah dan jumlah pembelian pakaian (Gitosudarmo, 2012:233), serta variabel minat beli dengan indikator membeli pakaian (Kotler dan Keller, 2012 : 131). Berdasarkan gambar tersebut, pola diskon diarahkan dapat menuju minat beli. Diskon yang menarik (harga murah dan jumlah pembelian pakaian) diharapkan dapat memberikan efek minat beli di benak konsumen, 
sehingga produk pakaian di Matahari Depatement Store Kediri Town Square dapat terjual.

Teknis analisis data menurut Miles dan Huberman terdiri dari 3 tahapan, antara lain yaitu : reduksi data, penyajian data, serta penarikan kesimpulan (Basrowi dan Suwandi, 2008). Reduksi data sebagai proses pemilihan, pemusatan perhatian dalam penyederhanaan, penggunaan abstrak dan melakukan transformasi data mentah dari lapangan yang dilakukan oleh peneliti. Selanjutnya penyajian data dapat diartikan sebagai kumpulan informasi yang disusun oleh peneliti untuk memberikan kemungkinan hasil dalam menarik kesimpulan serta mengambil tindakan berdasarkan informasi lapangan yang diperoleh.

Alur penelitian (gambar 2) yang dilakukan adalah pengamatan langsung dan wawancara kepada konsumen, melakukan analisis hasil dari lapangan, selanjutnya memberi kesimpulan berdasarkan hasil analisis tersebut. Pengamatan dilakukan dengan melihat perilaku konsumen terhadap tawaran diskon yang diberikan, sedangkan wawancara dilakukan dengan menanyakan kepada konsumen tentang tawaran diskon tersebut. Untuk minat beli akan dapat diamati pada posisi kasir tempat transaksi pembayaran dilakukan. Pada posisi kasir akan tampak komunikasi dua arah antara pihak kasir dan konsumen.

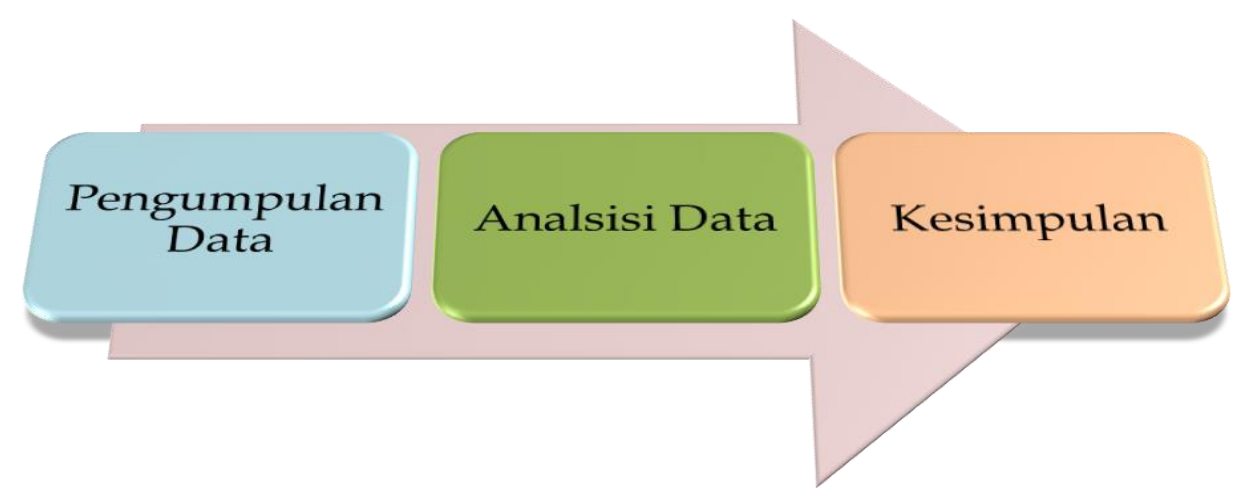

Gambar 2. Alur Penelitian, diolah, 2019.

Berdasarkan gambar 2, maka penelitian akan dijalankan dengan melakukan pengumpulan data dari konsumen selaku subyek penelitian di Matahari Departement Stote Kediri Town Square, selanjutnya melakukan analisis data serta 
membuat kesimpulan berdasarkan hasil yang telah dianalisis. Berdasarkan kesimpulan tersebut dapat diketahui seberapa jauh peranan penenarapan diskon dalam menarik minat beli konsumen, yang selanjutnya akan dilakukan pembandingan dengan hasil penelitian sebelumnya.

\section{PEMBAHASAN}

Matahari Depatement Store Kediri Town Square merupakan salah satu tempat penjualan pakaian di Kota Kediri. Pada tempat tersebut dijual berbagai jenis model pakaian dari berbagai macam merek. Kenaekaragaman merek memberikan nilai jual yang berbeda pada setiap pakaian. Harga tinggi menjadi ketakutan bagi konsumen. Untuk mengatasi hal tersebut, maka dberlakukan diskon dalam setiap pembelian produk pakaian. Keberadaan diskon menjadi sarana penjualan pakaian. Diskon sebagai harga yang lebih rendah, sehingga konsumen hanya membayar nilai yang diminta pembeli. Nilai diskon antar lain : waktu pembayaran yang lebih awal dar4i waktu yang yang ditentukan sebelumnya, jumlah pembelian yang dilakukan serta pembelian pada waktu tertentu seperti pada waktu hari raya dan sebagianya (Gitosudarmo, 2012 : 233). Indikator diskon adalah harga murah dan jumlah pembelian pakaian, sedang variabel minat beli dengan indikator membeli pakaian.

Pada indikator harga murah, variasi nilai diskon menjadi acuan konsumen dalam membeli produk tersebut. Perbedaan nilai diskon dalam pembelanjaan antara satu, dua, atau tiga produk pakaian menjadi pilihan tersendiri bagi konsumen. Ketertarikan konsumen dalam membeli tiga produk pakaian cenderung tinggi. Nilai diskon yang diberikan dengan memberikan satu produk pakaian dengan gratis menjadi pemicu konsumen untuk memanfaatkan program diskon dengan membeli tiga produk pakaian.

Indikator jumlah pembelian pakaian pada variabel diskon menunjukkan bahwa konsumen membeli produk pakaian dengan jumlah bervariasi. Konsumen ada yang membeli satu, dua, atau bahkan tiga pakaian dengan berbagai merek. Pola pikir konsumen yang membeli satu pakaian karena konsumen merasa cukup membeli satu pakaian saja. Pembelian dua pakaian, konsumen memiliki pola pikir karena mendapat diskon yang lebih banyak disbanding dengan membeli satu 
pakaian. Pada konsumen yang membeli tiga produk pakaian karena merasa mendapat keuntungan lebih dengan cukup membayar dua produk pakaian saja yang mana produk pakaian dengan harga terendah tidak perlu dibayar. Keanekaragaman pola pikir konsumen memberikan daya tarik tersendiri pada hasil penelitian. Diskon dapat memberikan nilai tersendiri pada pola pikir konsumen dalam memnetukan atau memilih produk yang akan dibeli.

Diskon terlihat menarik minat beli konsumen. Hal tersebut tampak dari minat konsumen dalam membeli pakaian. Minat beli sebagai sikap atau perilaku konsumen yang mempunyai keinginan untuk melakukan pembelian atau memilih suatu produk yang diinginkan, hal tersebut berdasarkan pengalaman, penggunaan dan kegiatan konsumsi produk (Kotler dan Keller, 2012 : 131). Indikator membeli pakaian pada variabel minat beli terlihat dari antrian pembeli yang akan melakukan transaksi di kasir. Pada antrian pembayaran di kasir terjalin komunikasi antara kasir dan pembeli dalam penerapan diskon yang dimaksud. Komunikasi yang terjadi adalah mengenai produk pakaian dan jumlah yang dibeli oleh konsumen serta nilai perolehan diskon yang diperoleh oleh konsumen. Konsumen akan memberikan pembenaran jika apa yang dinyatakan oleh kasir adalah benar. Tujuan dari komunikasi tersebut adalah supaya ada kejelasaan antara dua belah pihak antara kasir dan konsumen mengenai produk yang dibeli oleh konsumen.

Kasir melakukan percakapan dengan konsumen yaitu menyebutkan jumlah pakaian yang dibeli. Kasir menyebutkan nilai diskon yang diperoleh oleh pembeli. Keterkaitan diskon dan minat beli terlihat pada kegiatan transaksi tersebut. Konsumen cenderung tertarik untuk membeli pakaian dengan jumlah lebih banyak untuk mendapat diskon lebih banyak pula.

Penerapan diskon pada pembelian pakaian memberi efek baik. Minat beli tercipta dengan adanya penerapan diskon tersebut. Setidaknya konsumen akan membeli satu pakaian dengan demikian konsumen sudah mendapat diskon. Tetapi ada pula konsumen yang tertarik untuk membeli tiga pakaian dengan mendapatkan satu produk pakaian gratis (satu produk pakaian dengan harga terendah diberikan gratis). Hal tersebut merupakan cara yang tanpa disadari oleh konsumen untuk memancing keinginan membeli bagi konsumen. 
Hasil penelitian sejalan dengan hasil dari Putra E.W., Kumadji, S., dan Yulianto, E (2016) yang menyatakan diskon memiliki pengaruh signifikan pada minat beli; Sudrajat dkk (2017) yang dalam hasil penelitian mengungkapkan bahwa potongan harga berpengaruh terhadap keinginan atau minat beli konsumen. Sikap konsumen terhadap diskon dan hadiah memiliki efektifitas terhadap niat beli (Faesol, 2013). Sehingga penelitian menjawab rumusan masalah dan tujuan penelitian bahwa penerapan diskon dapat menarik minat beli para pembeli selaku konsumen di Matahari Departement Store Kediri Town Square.

Keberadaan diskon sebagai pemicu minat beli konsumen. Daya tarik nilai diskon yang ditawarkan akan memberi pilihan pada konsumen dalam menentukan jumlah pembelian. Berbagai cara diskon dilakukan dalam upaya penjual untuk meningkatkan penjualan produk. Metode diskon menjadi salah satu cara dalam meningkatkan keinginan beli konsumen.

\section{KESIMPULAN}

Diskon merupakan sesuatu yang dapat menarik minat beli. Dalam hasil penelitian diperoleh bahwa penerapan diskon dapat menarik minat beli para pembeli selaku konsumen di Matahari Departement Store Kediri Town Square. Keberadaan diskon menarik perhatian konsumen. Penawaran diskon yang menarik menjadi daya tarik tersendiri. Bersamaan hal tersebut, diskon menjadi daya tarik konsumen untuk membeli produk pakaian di tempat tersebut. Indikator harga murah dan jumlah pembelian pakaian pada variabel diskon memberi dampak positif pada minat beli konsumen dengan indikator membeli pakaian.

Penelitian ini menggunakan variabel diskon dan minat beli dengan produk pakaian, sementara di Matahari Departement Store juga terdapat produk lain seperti tas, sepatu, sandal, dan sebagainya yang juga memberi diskon pembelian. Peneliti selanjutnya dapat menggunakan produk selaian pakaian untuk diteliti apakah produk-produk tersebut dengan penerapan diskon juga menarik minat beli.

\section{DAFTAR PUSTAKA}

Alma, Buchari. (2004). Manajemen Pemasaran dan Jasa. Bandung : Alfabeta. 
Basrowi dan Suwandi. (2008). Memahami Penelitian Kualitatif.Jakarta : PT Rineka Cipta.

Boyd, W. (2010). Manajemen Pemasaran: Suatu Pendekatan Strategis Dengan Orientasi Global (Edisi Kedua). Jakarta: Erlangga.

Faesol, Amir. (2013). Efektivitas diskon dan hadiah sebagai sarana promosi penjualan untuk menarik niat beli konsumen pada bumbu magic lezat. Jurnal Manajemen Bisnis, (3) 01, 44 - 53.

Gitosudarmo, I.(2012). Manajemen Pemasaran (Edisi Kedua).Penerbit : BPFE Yogyakarta

Kotler, Philip., Kevin Lane, Keller. 2007. Manajemen Pemasaran: Edisi Kedua Belas Jilid 2. Diterjemahkan Oleh Benyamin Molan. Jakarta: PT. INDEKS.

Kotler, Philip Dan Gary Armstrong. (2008). Prinsip-Prinsip Pemasaran. Jilid 1 Edisi 12. Alih Bahasa : Bob Sabran. Jakarta : Penerbit Erlangga.

Kotler, Philip Dan Kevin Lane Keller. (2012). Marketing Management 13. New Jersey: Pearson Prentice Hall, Inc.

Oentoro Deliyanti. (2012). Manajemen Pemasaran Modern, Edisi Kesembilan, Jilid 1 Dan Jilid 2. Jakarta, Prehalindo, Penerbit Laksbang Pressindo, Yogyakarta.

Putra, E. W., Kumadji, S., dan Yulianto, E. (2016). Pengaruh Diskon Terhadap Minat Beli Serta Dampaknya Pada Keputusan Pembelian(Study Pada Konsumen Yang Membeli Produk Diskon Di Matahari Department Store Pasar Besar Malang). Jurnal Administrasi Bisnis (JAB), 38 (2), 184 - 193.

Rahayu, DWS. (2018). Merek Sebagai Pendorong Keputusan Pembelian Produk Kosmetik Make Over Di Kota Blitar. Jurnal Akuntabilitas, (11) 2, 20-27.

Sudrajat, R. H., Putri, B. P. S., dan Putri, C. N. (2017). Pengaruh potongan harga terhadap minat beli (studi pada potongan harga di iklan televisi bukalapak.com versi hari belanja. Online nasional 2015 terhadap minat beli remaja di kota bandung). E-Proceeding Of Management , (4)1, 972.

Wibowo, R., dan Japarianto, E. (2013). Pengaruh retail mix terhadap minat beli di keraton department store. Jurnal Manajemen Pemasaran, (1) 1, 1-12. 